\title{
A STUDY ON CYBER CHILD PORNOGRAPHY
}

\author{
Mrs.NIRANJANA. $K^{* 1}$, Dr. MURUGAN RAMU **2 \\ ${ }^{1}$ ASSISTANT PROFESSOR, SAVEETHA SCHOOL OF LAW, SAVEETHA INSTITUTE OF MEDICAL AND TECHNICAL \\ SCIENCES (SIMATS) \\ ${ }^{2}$ ASSOCIATE PROFESSOR, DEPARTMENT OF MANAGEMENT STUDIES, SAVEETHA SCHOOL OF LAW \\ SAVEETHA INSTITUTE OF MEDICAL AND TECHNICAL SCIENCES (SIMATS)
}

\begin{abstract}
This article details about cyber child Pornography, Pornography is not only an emerging issue in India but also over all the worlds. A worst and adverse effect of the technology can be seen in this era. The word pornography is defined as "writing, photographs, movies etc. intended to arouse sexual excitement." The objectives of the research paper: to study about pornography and its adverse impact on society and to critically analyze whether pornography is violence in media with reference to legal issues and challenges on pornography in India. The research has used empirical methodology, it has been proceeded with a method of random sampling. The article has also dealt with various issues and challenges of cyber child pornography in India. One third of the internet is covered by porn-sites which are leading to exploitation oppression of women and children. While nobody will take into account himself or herself proof against the corrupting effects of creation and violence or safe from injury at the hands of these acting underneath their influence, the young and therefore the immature ar particularly vulnerable and therefore the presumably to be victimized. Through this article researcher highlights about pornography, and the public opinion about cyber child pornography and the existing laws to prevent. Findings and conclusion Researcher emphasizes through this article the adverse impact of it on society, children and women and recommended strong control of law over it because there is a increasing rate of children in pornography and media been used a forum to expand. So, there must be stringent to combat cyber child pornography.
\end{abstract}

KEYWORDS: Pornography, Children, Legal Issues, Children, Combat.

Article Received: 10 August2020,Revised:25October2020,Accepted: 18 November 2020

\section{INTRODUCTION:}

Sex could be a debatable subject within the social cloth of India, usually being coupled to immoral and lubricious values. The word "pornography" comes from the Greek "pornographos" virtually that means writing regarding prostitutes. one in all the unremarkably accepted definitions of "pornography" in nowadays defines

it as sexually specific material (verbal or pictorial) that's primarily designed to supply arousal in viewers. When price judgments ar connected to the present definition, creation is perceived as sexually specific material designed to supply arousal in customers that's dangerous during a sure approach.(Cline \&Berns 1974)There are several approaches to outline creation like any sexually specific material that's dangerous, though a very dominant approach has been to outline creation in terms of obscenity. This is conjointly the apply followed in India, wherever creation is seen as associate degree aggravated variety of obscenity.(Boyle 2010)Many conservatives and feminists believe they'll each de- ne and just ably condemn creation since in step with them it lacks intellectual or aesthetic advantage, is harmful to the viewers and damages the ethical cloth of the society. The current laws criminalize mercantilism, distributing and in public displaying obscene or sexy material. the first concern underlying this can be safeguarding of public morality and decency.(Mercer \& Perkins 2014) However such laws cause the violation of individual liberty and ethical independence of someone World Health Organization desires to relish pornography as his right to look at, browse or relish creation (that may be browse into his freedom of speech and expression, and/or the correct to privacy underneath the Indian constitution) is curtailed.

Pornography within the media is known as a violation, through the employment of audiovisual techniques, of 
the correct to privacy of the physical body in its male or feminine nature, a violation that reduces the human person associate degreed physical body to an anonymous object of misuse for the aim of gratifying concupiscence; violence within the media is also understood particularly during this context - as a presentation designed to charm to base human instincts of actions contrary to the dignity of the person and depiction intense physical force exercised during a deeply offensive and infrequently choleric manner. (Mercer \& Perkins 2014; Bond \& Tyrrell 2018)Specialists could disagree among themselves regarding however and to what degree explicit people and teams ar laid low with these phenomena, however the broad outlines of the matter ar stark, clear and horrifying.(Larsen1994)

While nobody will take into account himself or herself proof against the corrupting effects of creation and violence or safe from injury at the hands of these acting underneath their influence, the young and therefore the immature ar particularly vulnerable and therefore the presumably to be victimised. creation and sadistic violence debase gender, corrode human relationships, exploit people - particularly ladies and teenagers, undermine wedding and family life, foster anti-social behaviour and weaken the ethical fibre of society itself..(Boyle 2005)Thus, one in all the clear effects of creation is sin..(Carter \& Cynthia 2003) Willing participation within the production or dissemination of those toxic product will solely be judged a heavy ethical evil. Likewise, production and dissemination of those materials couldn't continue if there have been not a marketplace for them, therefore people who use such materials not solely do ethical damage to themselves however contribute to the continuation of a villainous trade.Frequent exposure to violence within the media may be confusing to youngsters, World Health Organization might not be able to distinguish pronto between fantasy and reality.(Purcell 2012) At a later stage, violence within the media will condition pliant persons, particularly people who are young, to take this as traditional and acceptable behaviour, appropriate for imitation.It has even been same that there may be a psychological link between creation and sadistic violence, and a few creation is itself overtly violent in theme and content. people who read or browse such material run the chance of carrying over such attitudes and behavior into their own relationships and may return to lack reverence and respect for others as precious youngsters of God and as brothers and sisters within the same human family. (Makin \&Morczek 2016).Such a link between creation and sadistic violence has explicit implications for those affected by sure styles of psychological state.(Simons et al. 2008)

There square measure indications that the incidence of violence in society could also be associated with the abundance of depictions of violence shown on tv, video, the web and in laptop games. Wright and Tokunaga 2016) larger accessibility of erotica in today's media is another issue that causes concern regarding young people's welfare and attainable negative impacts on young people's development. for instance, what concepts regarding physiological property will erotica instill? numerous measures to limit the distribution of content that's believed to be harmful to kids and youth are mentioned. These embrace each voluntary measures and binding legislation.(Wright \& Tokunaga 2016) Dialogues between authorities, media firms and members of the final public are initiated with a read to establishing accord on basic principles. These dialogues square measure happening at national, regional and international levels.In recent years we've got seen a shift in stress from concepts regarding legislative regulation and prohibition toward a stress on parents' and alternative adults' responsibility for the well-being of youngsters and children. 'Protection' is currently understood to be over an issue of keeping kids faraway from bound tv programs, however extends to strengthening young viewers in their roles as shoppers and users of media.(Carter \& Cynthia 2003).The aim of the study is to study about cyber child pornography and its impact on society by analyzing the existing laws in India to combat it .

\section{OBJECTIVES}

- To highlights about cyber child pornography

- To analyze its impact on society

- To analyze about the existing laws in controlling cyber child pornography in India.

\section{REVIEW OF LITERATURE:}

The researchers has reviewed the following books such as Media and Society: A Critical Perspective authored by Arthur Asa Berger. In this book they have analysed about the owners of the media are the ones who call the 
tunes, nowadays. (DeKeseredy\&Corsianos 2015)They publish the giant media conglomerates can help shape our ideologies in a number of different ways. First, their Beauty, as they say, is in the eye of the beholder, and so, it seems, is the determination of what is and what is not pornography. In this book Violence against Women in Pornography authored by Walter DeKeseredy, Marilyn Corsianos, the book clearly depicts about the main objective of this book is to motivate readers to think critically about adult pornography and to take progressive steps individually and collectively to curb the production and consumption of hurtful sexual media.Ordinary experience confirmed by studies conducted around the world has recognized the evil effects of pornography and violence in the media.(Gidycz et al. 2011)Pornography in the media is understood as a violation, through the use of audiovisual techniques, of the right to privacy of the human body in its male or female nature, a violation which reduces the human person and human body to an anonymous object of misuse for the purpose of gratifying concupiscence; violence in the media may be understood - especially in this context - as a presentation designed to appeal to base human instincts of actions contrary to the dignity of the person and depicting intense physical force exercised in a deeply offensive and often passionate manner(Hald\&Malamuth 2015). Specialists may disagree among themselves about how and to what degree particular individuals and groups are affected by these phenomena, but the broad outlines of the problem are stark, clear and frightening. The book Influences of Media Violence: A Brief Research Summary authored by Cecilia Von feilitzen they have approached on many studies with different theories and methods. The research findings are presented in the following areas: limitation; aggression (including the influence of different kinds of violence); fear; conceptions of violence in reality; habituation; constructive actions; excitement; identity seeking/group belonging; and working through problems, understanding, or knowledge. (Hald\&Malamuth 2015; Coon \&Mitterer 2012)The review also touches on research that explores media violence through the lenses of other media content, culture at large, and political economy. (Rothman et al. 2017)Based on the review, it was concluded that, looking beyond direct and simple causal relations between media violence and aggression, everyone receives impressions from and is in some way negatively influenced by media violence, although in different ways based on varying motives, intentions, wishes, and life conditions.

Violence And The Media authored by Carter, Cynthia approaches Violence and the Media is a lively and indispensable introduction to current thinking about media violence and its potential influence on audiences.Adopting a fresh perspective on the media effects debate, Carter and Weaver engage with a host of pressing issues around violence in different media contexts - including news, film, television, pornography, advertising and cyberspace.(Mercer 2013) The book Pornography: The Production and Consumption of Inequality authored by Gail Dines, Bob Jensen, Ann Russo it talks about There are some beautiful beaches in the world that have hidden dangers. When water floods sand below the surface, the sand particles get pushed apart. The result is a muddy mixture of the two that can't support the weight of a person. When someone walks over it, they sink down. It's a trap known as quicksand. As the person sinks down, it pushes the water out creating a vacuum effect that secures its victim tighter and tighter. Sometimes it only takes moments to absorb someone into a desperate situation. This is what pornography does to millions every day. It starts simple enough without any sign of danger, a movie on cable or the click of the mouse. We tell ourselves there's nothing wrong with it, or perhaps it's not that bad, even though we keep it secret. Pretty soon what started as "controllable" and "here and there" turns into a habit, deeper and deeper. But the user is not the only one affected. The consequences for our society as a whole is alarming. Knowing the dangers and taking them seriously will allow us to avoid getting ensnared. (Anon n.d.)The fate of the next generation depends on us.

By some estimates, it grosses more revenue per year than the entire "legitimate" film and entertainment industry. Most large hotel chains offer pay-for-view adult movies, many video stores have adult movie rental sections, and Internet porn sites have proliferated by the thousands. With porn so ubiquitous in mainstream American culture, why is it that when "respectable" people talk about this phenomenon, they act puzzled, as if they cannot imagine who would watch such worthless and meaningless smut? In this collection of path-breaking essays, thirteen respected scholars bring critical insights to the reality of porn and what it can tell us about ourselves sexually, culturally, and economically. 
(Mercer \& Parkinson 2014)Moving beyond simplistic feminist and religious positions that cast these films as categorical evils-a collective preserve of sexual perversion, misogyny, pedophilia, and racism-the contributors to this volume raise the bar of the debate and push porn studies into intriguing new territory. The essays are divided into two sections. The first reprints important debates on the topic and traces the evolution of pornographic film, including comparing its development to that of Hollywood cinema. The second part presents new essays that consider current trends in the field, including pornography's expansion into new technologies(Mercer \& Parkinson 2014; Sun et al. 2016).This book separates this compelling genre from the sensation and shame that have long surrounded and obscured it. It will be of interest to general readers and film scholars alike.

\section{METHODOLOGY:}

The methodology used in this study is empirical research.Empirical research is based on observed and measured phenomena and derives knowledge from actual experience rather than from theory or belief.Empirical research is where you conduct "hands on" experimentation. In other words, you get your results from actual experience rather than from a theory or belief. The idea that knowledge is largely attained the through exploration of concepts, deduction, intuition and revelation. The sample size of the survey is 1516 and the survey has been conducted on random sampling.

The study was limited to a certain extent as the general public were not interested in answering the survey conducted due to their work shifts and most probably many of them were not willing to spend time on the questions the survey was limited to 1516 individuals. The independent variables are Age, Qualification and Gender, the dependent variables are Do you think a separate legislation for cyber child pornography could control and reduce the effect of it.The research tool used for this article is frequency, crosstab, chi Square and Anova based on this the research has been carried out by proving the hypothesis.

\section{ANALYSIS AND DISCUSSION:}

The hypothesis of this research are Cyber Child Pornography in India is not increasing because the law to combat cyber child pornography is not effective in nature and Cyber Child Pornography in India is increasing because the law to combat cyber child pornography is effective in nature. The null hypothesis has been rejected that From the above table the $\mathrm{p}$ value 0.127 is greater than 0.005 which means ,the null hypothesis has been accepted and there is no relation between two variables. It can be said clearly that the independent variable gender and the dependent variable " Do you think that children are involved in pornography" have no relationship between them . And here by accepting the null hypothesis cyber child pornography in India is not increasing because the law to combat cyber child pornography is effective in nature. While nobody will take into account himself or herself proof against the corrupting effects of creation and violence or safe from injury at the hands of these acting underneath their influence, the young and therefore the immature ar particularly vulnerable and therefore the presumably to be victimised.

TABLE 1 GENERAL VIEW ON CHILD PORNOGRAPHY

\begin{tabular}{|c|c|c|c|c|c|c|}
\hline \multicolumn{7}{|c|}{ Crosstab } \\
\hline \multicolumn{7}{|c|}{ Do you think children are involved in Pornography? } \\
\hline & & & Yes & no & May be & Total \\
\hline \multirow[t]{4}{*}{ Gender } & female & Count & 204 & 418 & 8 & 630 \\
\hline & & $\begin{array}{l}\% \quad \text { within } \\
\text { Gender }\end{array}$ & $32.4 \%$ & $66.3 \%$ & $1.3 \%$ & $100.0 \%$ \\
\hline & male & Count & 316 & 506 & 12 & 834 \\
\hline & & $\begin{array}{l}\% \quad \text { within } \\
\text { Gender }\end{array}$ & $37.9 \%$ & $60.7 \%$ & $1.4 \%$ & $100.0 \%$ \\
\hline
\end{tabular}




\begin{tabular}{|l|l|l|l|l|l|l|}
\hline \multirow{2}{*}{$\begin{array}{l}\text { prefer } \\
\text { not to } \\
\text { say }\end{array}$} & \begin{tabular}{l} 
Count \\
\cline { 3 - 6 } \\
Total within
\end{tabular} & 23 & 29 & 0 & 52 \\
\hline & Gender & Count & 543 & $55.8 \%$ & $0.0 \%$ & $100.0 \%$ \\
\cline { 2 - 6 } & $\begin{array}{l}\% \text { within } \\
\text { Gender }\end{array}$ & $35.8 \%$ & 653 & 20 & 1516 \\
\hline
\end{tabular}

From the above table 6, the above responses have been recorded with reference to the question " Do you think that children are involved in pornography" . A total count of 1516 responses have been recorded of which $32.4 \%$ are recorded from female who responses are positive in nature and $66.3 \%$ are recorded in negative nature and $1.3 \%$ in neutral from the female respondents. Based on the male respondents $37.9 \%$ have approach of accepting it and $60.7 \%$ are denying to the question imposed and $1.4 \%$ are partially accepting and denying it. And some of them are not interested in saying their gender and among them $44.2 \%$ are giving positive approach , 55.8\% negative approach As a whole a total percentage of $35.8 \%$ are recorded on accepting the question imposed and $62.9 \%$ of denying it and $1.3 \%$ partial in nature.

\begin{tabular}{|c|c|c|c|}
\hline \multicolumn{4}{|l|}{ Chi-Square Tests } \\
\hline & Value & Df & Asymp. Sig. (2-sided) \\
\hline Pearson Chi-Square & $7.164 a$ & 4 & .127 \\
\hline Likelihood Ratio & 7.829 & 4 & .098 \\
\hline Linear-by-Linear Association & 5.980 & 1 & .014 \\
\hline $\mathrm{N}$ of Valid Cases & 1516 & & \\
\hline
\end{tabular}

From the above table the $p$ value 0.127 is greater than 0.005 which means ,the null hypothesis has been accepted and there is no relation between two variables. It can be said clearly that the independent variable gender and the dependent variable "Do you think that children are involved in pornography" have no relationship between them . And here by accepting the null hypothesis cyber child pornography in India is not increasing because the law to combat cyber child pornography is effective in nature. While nobody will take into account himself or herself proof against the corrupting effects of creation and violence or safe from injury at the hands of these acting underneath their influence, the young and therefore the immature ar particularly vulnerable and therefore the presumably to be victimized.

ANOVA

Do you think children are involved in Pornography?

\begin{tabular}{|l|l|l|l|l|l|}
\hline & 11.807 & 2 & 5.904 & 24.091 & .000 \\
\hline
\end{tabular}




\begin{tabular}{|l|l|l|l|l|l|}
\hline Between Groups & & & & & \\
\hline Within Groups & 370.765 & 1513 & .245 & & \\
\hline Total & 382.572 & 1515 & & & \\
\hline
\end{tabular}

From the above table 8 , the $\mathrm{p}$ value 0.000 is lesser than 0.005 which means ,the null hypothesis has been rejected and there is relation between two variables. While nobody will take into account himself or herself proof against the corrupting effects of creation and violence or safe from injury at the hands of these acting underneath their influence, the young and therefore the immature ar particularly vulnerable and therefore the presumably to be victimised. It can be said clearly that the independent variable Qualification and the dependent variable "Do you think children are involved in pornogtaphy"have relationship between them . And here by rejecting the null hypothesis cyber child pornography in India is increasing because the law to combat cyber child pornography is not effective in nature.

\section{TABLE 2 GENERAL VIEW ON LEGISLATION CONTROL OVER CYBER CHILD PORNOGRAPHY AND ITS} EFFECT.

\begin{tabular}{|c|c|c|c|c|c|c|}
\hline \multicolumn{7}{|c|}{ Crosstab } \\
\hline \multicolumn{7}{|c|}{$\begin{array}{l}\text { Do you think a separate legislation for cyber child Pornography could control and reduce the effect of } \\
\text { it? }\end{array}$} \\
\hline & & & Yes & no & May be & Total \\
\hline \multirow[t]{6}{*}{ Gender } & \multirow[t]{2}{*}{ female } & Count & 403 & 220 & 7 & 630 \\
\hline & & $\begin{array}{l}\% \quad \text { within } \\
\text { Gender }\end{array}$ & $64.0 \%$ & $34.9 \%$ & $1.1 \%$ & $100.0 \%$ \\
\hline & \multirow[t]{2}{*}{ male } & Count & 415 & 405 & 14 & 834 \\
\hline & & $\begin{array}{l}\% \quad \text { within } \\
\text { Gender }\end{array}$ & $49.8 \%$ & $48.6 \%$ & $1.7 \%$ & $100.0 \%$ \\
\hline & \multirow{2}{*}{$\begin{array}{l}\text { prefer not } \\
\text { to say }\end{array}$} & Count & 27 & 25 & 0 & 52 \\
\hline & & $\begin{array}{l}\% \quad \text { within } \\
\text { Gender }\end{array}$ & $51.9 \%$ & $48.1 \%$ & $0.0 \%$ & $100.0 \%$ \\
\hline \multirow{2}{*}{\multicolumn{2}{|c|}{ Total }} & Count & 845 & 650 & 21 & 1516 \\
\hline & & $\begin{array}{l}\% \quad \text { within } \\
\text { Gender }\end{array}$ & $55.7 \%$ & $42.9 \%$ & $1.4 \%$ & $100.0 \%$ \\
\hline
\end{tabular}

From the above table 6, the above responses have been recorded with reference to the question " Do you thinka separate legislation for cyber child pornographers could control and reduce the effect" . A total count of 1516 responses have been recorded of which $64.0 \%$ are recorded from female who responses are positive in nature and $34.9 \%$ are recorded in negative nature and
$1.1 \%$ in neutral from the female respondents. Based on the male respondents $49.8 \%$ have approach of accepting it and $48.6 \%$ are denying to the question imposed and $1.7 \%$ are partially accepting and denying it. And some of them are not interested in saying their gender and among them $51.9 \%$ are giving positive approach , $48.1 \%$ negative approach . As a whole a total percentage of 
$55.7 \%$ are recorded on accepting the question imposed and $42.9 \%$ of denying it and $1.4 \%$ partial in nature.

Chi-Square Tests
\begin{tabular}{|l|l|l|l|}
\hline & Value & df & Asymp. Sig. (2-sided) \\
\hline Pearson Chi-Square & $30.633 \mathrm{a}$ & 4 & .000 \\
Likelihood Ratio & 31.562 & & \\
Linear-by-Linear & 23.602 & 4 & .000 \\
Association & & 1 & .000 \\
N of Valid Cases & 1516 & & \\
\hline
\end{tabular}

a. 1 cells $(11.1 \%)$ have expected count less than 5 . The minimum expected count is .72 .

From the above table the $\mathrm{p}$ value 0.000 is , lesser than 0.005 which means ,the null hypothesis has been rejected and there is relation between two variables. It can be said clearly that the independent variable gender and the dependent variable "Do you thinka separate legislation for cyber child pornographers could control and reduce the effect" have relationship between them . And here by rejecting the null hypothesis cyber child pornography in
India is increasing because the law to combat cyber child pornography is not effective in nature. While nobody will take into account himself or herself proof against the corrupting effects of creation and violence or safe from injury at the hands of these acting underneath their influence, the young and therefore the immature ar particularly vulnerable and therefore the presumably to be victimised

\section{ANOVA}

\begin{tabular}{|c|c|c|c|c|c|}
\hline $\begin{array}{l}\text { Do you think a sep } \\
\text { control and reduce th }\end{array}$ & $\begin{array}{l}\text { e legisla } \\
\text { fect of it }\end{array}$ & on fo & & Porr & hy \\
\hline Between Groups & 1.432 & 2 & .716 & 2.600 & .075 \\
\hline Within Groups & $\begin{array}{l}416.69 \\
4\end{array}$ & 1513 & .275 & & \\
\hline Total & $\begin{array}{l}418.12 \\
7\end{array}$ & 1515 & & & \\
\hline
\end{tabular}

From the above table 9 , the $\mathrm{p}$ value 0.075 is greater than 0.005 which means, the null hypothesis has been accepted and there is no relation between two variables. It can be said clearly that the independent variable Qualification and the dependent variable " Do you think a separate legislation for cyber child pornography could control and reduce the effect of it" have no relationship between them. And here by accepting the null hypothesis cyber child pornography in India is not increasing because the law to combat cyber child pornography is effective in nature. While nobody will take into account himself or herself proof against the 
corrupting effects of creation and violence or safe from injury at the hands of these acting underneath their influence, the young and therefore the immature ar particularly vulnerable and therefore the presumably to be victimised.

\section{FINDINGS AND DISCUSSION}

Children being weak, gentle and meek should be protected from the world of criminals, shady people, and negative people and so on. They being the most voiceless and defenceless group, require special attention for protection of their human rights. It is indeed the duty of the society at large, including the legal and judicial authorities, to protect those who are helpless to protect themselves, and this is especially true for children. But, at times, these vulnerable kids fall prey to the predators of child abuse, child trafficking, child pornography, begging etc. They find themselves entangled in the world of disgrace, inhumanity and disrespectfulness from which they hardly escape or look for a shine of hope. With the introduction of the modern information technology they get entrapped into new modes of crime especially child abuse, child labour and child pornography. Child Pornography has been exclusively dealt with under Section 67B of the Information Technology Act, 2008. Depicting children engaged in sexually explicit act, creating text or digital images or advertising or promoting such material depicting children in obscene or indecent manner etc. or facilitating abusing children online or inducing children to online relationship with one or more children etc. come under this Section. 'Children' means persons who have not completed 18 years of age, for the purpose of this Section. Punishment for the first conviction is imprisonment for a maximum of five years and fine of ten lakh rupees and in the event of subsequent conviction with Imprisonment of seven years and fine of ten lakh rupees. The present paper will critically discuss the problem of child pornography in the digital world and the international and national measures to curb this problem. Parents and family members should interact with children regularly creating awareness about safety and abuses including sexual abuses being inflicted on them and how to avoid and to raise alarm in case of any attempt to abuse. The parents should interact regularly with the children so that if any abuse is made which can be found out even if the child does not voluntarily report. School authorities should create awareness about the child abuses. If any behavioral change in the student is noted the same should be brought to the notice of the parents and enquire the child in a conducive atmosphere to find out any abuse has been inflicted. Media should also play active role in educating and sensitizing the society about child abuses and sex offences by giving required publicity about the existing laws against sexual offences especially child sexual offences. People should be educated to note the behavioral changes of the children and find out the reasons for abuses to save the child from trauma which may be prolonged. The investigating agencies should coordinate with NGOs, who are working for the welfare of children and prevention of child abuse by foreign nationals. There should be efforts by all to revive the disintegrated joint family system for more benefits including safety of children.

Children should be taught to be careful with the strangers.

\section{CONCLUSION:}

Cyber child Pornography within the media is known as a violation, through the employment of audiovisual techniques, of the correct to privacy of the physical body in its male or feminine nature, a violation that reduces the human person associate degreed physical body to an anonymous object of misuse for the aim of gratifying concupiscence; violence within the media is also understood - particularly during this context - as a presentation designed to charm to base human instincts of actions contrary to the dignity of the person and depiction intense physical force exercised during a deeply offensive and infrequently choleric manner. The major objectives of the paper are highlights about pornography andit's the adverse impact on society, find out the legal issues and challenges on pornography in India and to analyses whether pornography is a violence in media. The researcher has proved that pornography us a violence in media and it promoting pornography to the next level. Now, with the event of the net, the regulation of pornographic material has become rather more troublesome. kids will access pornographic materials from their homes or perhaps from public libraries, and ineligible materials can simply be disseminated. Anyone with a scanner and a electronic equipment will post obscene pictures, Which area unit offered to lots of folks. Indeed, each day further sites dedicated to erotica area unit created. the net was originally designed Department 
of Defense as a method of providing decentralized laptop controls. the idea was that if a part of the country were destroyed by a nuclear attack, the pc systems containing war designing would still be purposeful. before long the opportunities of the net became clear to the; personal sector. Universities and businesses created connections to what has been termed "the data superhighway" and that eventually junction rectifier to what's nowadays called the planet Wide net

\section{REFERENCES}

1. Anon, Theories of Media Violence. In On Media Violence. pp. 11-24.

2. Bond, E. \& Tyrrell, K., 2018. Understanding Revenge Pornography: A National Survey of Police Officers and Staff in England and Wales. Journal of interpersonal violence, p.886260518760011.

3. Boyle, K., 2010. Everyday Pornography, Routledge.

4. Boyle, K., 2005. Media and Violence: Gendering the Debates, SAGE.

5. Carter \& Cynthia, 2003. Violence And The Media, McGraw-Hill Education (UK).

6. Cline, V.B. \&Berns, W., 1974. Where do you draw the line?: An exploration into media violence, pornography, and censorship,

7. Coon, D. \&Mitterer, J.O., 2012. Introduction to Psychology: Gateways to Mind and Behavior with Concept Maps and Reviews, Cengage Learning.

8. DeKeseredy, W. \&Corsianos, M., 2015. Violence against Women in Pornography, Routledge.

9. Gidycz, C.A., Orchowski, L.M. \& Berkowitz, A.D., 2011. Preventing sexual aggression among college men: an evaluation of a social norms and bystander intervention program. Violence against women, 17(6), pp.720-742.

10. Hald, G.M. \&Malamuth, N.N., 2015. Experimental effects of exposure to pornography: the moderating effect of personality and mediating effect of sexual arousal. Archives of sexual behavior, 44(1), pp.99-109.

11. Larsen, O.N., 1994. Voicing Social Concern: The Mass Media, Violence, Pornography, Censorship, Organization, Social Science, the Ultramultiversity, University Press of Amer.
12. Makin, D.A. \&Morczek, A.L., 2016. X Views and Counting: Interest in Rape-Oriented Pornography as Gendered Microaggression. Journal of interpersonal violence, 31(12), pp.2131-2155.

13. Mercer, D., 2013. Girly mags and girly jobs: pornography and gendered inequality in forensic practice. International journal of mental health nursing, 22(1), pp.15-23.

14. Mercer, D. \& Parkinson, D., 2014. Video gaming and sexual violence: rethinking forensic nursing in a digital age. Journal of forensic nursing, 10(1), pp.27-35.

15. Mercer, D. \& Perkins, L., 2014. Theorising sexual media and sexual violence in a forensic setting: men's talk about pornography and offending. International journal of law and psychiatry, 37(2), pp.174-182.

16. Purcell, N.J., 2012. Violence and the Pornographic Imaginary: The Politics of Sex, Gender, and Aggression in Hardcore Pornography, Routledge.

17. Rothman, E.F. et al., 2017. A Qualitative Study of What US Parents Say and Do When Their Young Children See Pornography. Academic pediatrics, 17(8), pp.844-849.

18. Simons, D.A., Wurtele, S.K. \& Durham, R.L., 2008. Developmental experiences of child sexual abusers and rapists. Child abuse \& neglect, 32(5), pp.549-560.

19. Sun, C. et al., 2016. Pornography and the Male Sexual Script: An Analysis of Consumption and Sexual Relations. Archives of sexual behavior, 45(4), pp.983-994.

20. Wright, P.J. \& Tokunaga, R.S., 2016. Men's Objectifying Media Consumption, Objectification of Women, and Attitudes Supportive of Violence Against Women. Archives of sexual behavior, 45(4), pp.955-964.

21. Jain, Gagan, and Mukta Singhvi. "INTERNET PORNOGRAPHY: A NEW FORM OF VULNERABILITY FOR THE YOUTH." IMPACT: International Journal of Research in Humanities, Arts and Literature (IMPACT: IJRHAL) 7.1 (2019) 15-26

22. RAMEEZA, M., SA MUHAMMED ABRAAR, and N. SURESH. "FINITE ELEMENT ANALYSIS OF THE MODIFIED TURRET 
LIFTING HOOKS OF COMBAT VEHICLE." International Journal of Mechanical and Production Engineering Research and Development (IJMPERD) 8.6 (2018) 755-772

23. LOKESHWARI, RK, et al. "THE NUTRITIONAL GOLDMINE WASTE: THE SPENT PUPAE OF MULBERRY, ERI AND OAK TASAR SILKWORMS FOR COMBATING MALNUTRITION." International Journal of Environment, Ecology, Family and Urban Studies (IJEEFUS) 9.2 (2019) 129-138

24. Islam, Barrister Afrin. "CIVIL AND CRIMINAL ENFORCEMENT TO COMBAT WHITE COLLAR CRIME: A COMPARATIVE ANALYSIS." IMPACT: International Journal of Research in Humanities, Arts and Literature (IMPACT: IJRHAL) 6.2 (2018) 351-366

25. Seddeek, Abeer M. Refky M. "COMBATING CONVENTIONAL REALISM AND COMMODITY FETISHISM IN REPRESENTATION OF EVERYDAY LIFE: A STUDY OF RON SILLIMAN'S BART ON BART." International Journal of Linguistics and Literature (IJLL) 7.5 (2018) 33-48

26. IBRAHIM, SHEHU SIDI, and I. IBRAHIM HADIZA. "CHILD LANGUAGE ACQUISITION IN RELATION TO REDUPLICATION: A CASE STUDY OF 6 (SIX) TWO-YEAR-OLD HAUSA CHILDREN." International Journal of Humanities and Social Sciences (IJHSS) 5.6 (2016): 113-124. 